\title{
Estimation of Relationship Between In Situ and In Vitro Rumen Protein Degradability of Extruded Full Fat Soybean
}

\author{
Arzu Erol Tunç ${ }^{1}$, Yusuf Cufadar², Sema $\operatorname{Yaman}^{3 *}$ \\ ${ }^{I}$ International Center for Livestock Research and Training, 06852 Ankara, Turkey \\ ${ }^{2}$ Department of Animal Science, Faculty of Agriculture, Selçuk University, 42130 Konya, Turkey \\ ${ }^{3}$ Department of Animal Production and Technologies, Faculty of Agricultural Sciences and Technologies, Niğde Ömer Halisdemir \\ University, 51240 Niğde, Turkey

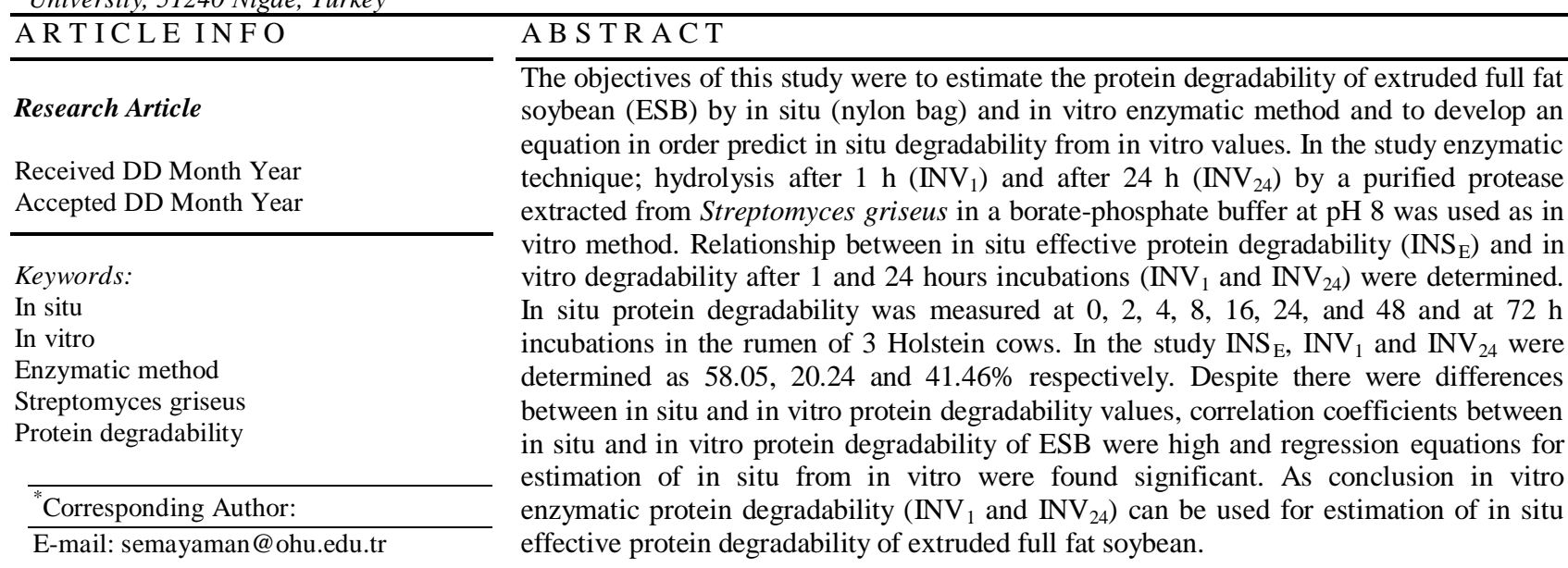

DOI: https://doi.org/10.24925/turjaf.v5i10.1237-1242.1426

\section{Introduction}

Ruminants differ significantly from other animals due to their unique digestive physiology. The microbial protein synthesized by rumen microorganisms is not sufficient to provide the high protein requirements of dairy cows in early lactation, early weaning calf and lambs especially (Broderick et al., 1988). Biologically high-protein value proteins that are enzymatically digested in abomasum and small intestines and not degradable in the rumen give better results when they are fed to high-yielding ruminants (Broderick et al., 1988). In order to provide the protein requirements of ruminants correctly, feed $\mathrm{N}$ compounds should be defined according to ruminal degradability characteristics such as rumen degradable protein (RDP) and rumen undegradable protein (RUP) (AFRC, 1987; Chamberlain and Wilkinson, 1998; Cömert and Sayan, 2000; McDonald et al., 2011).

There are a number of methods that involve different procedures used to determine the rumen degradability of feedstuffs. These methods can be classified as in vivo, in situ and in vitro methods. The in vivo method is usually the standard; but it is expensive and time consuming. Therefore, faster and cheaper methods have been developed which are in situ and in vitro methods. In situ method (nylon bag) is mostly accepted and used as a reference method to determine the RDP and RUP of feedstuffs. The exponential model developed by Orskov and McDonald (1979) has been widely used. Because in vivo and in situ methods require cannulated animals and the routine use of these techniques in the evaluation of feedstuffs are difficult. In vitro methods are needed which can be used in accurately estimating the ruminal degradability of feedstuffs. In these methods; buffer solutions purchased from commercial companies, buffer solutions extracted from rumen, chemical solutions, rumen liquid and enzymes were used. In contrast, for feed mixtures, the prediction very precise and much better with enzymatic method than the solubility method (Aufrere et al., 1991). Many researchers (Krishnamoorty et al., 1983; Poos Floyd et al., 1985; Susmel et al., 1989; Aufrere et al., 1991; Roe et al., 1991; Assoumani et al., 1992; Calsamiglia and Stern, 1995) have reported that there was a high correlation between in situ protein degradability values and protein degradability values obtained by enzymatic in vitro methods.

A number of enzymatic methods have been proposed by researchers to predict the digestibility of feedstuffs. In particular, methods using commercial proteases provide 
advantages in terms of labour and time. Proteases with different origins have been tested by some researchers to determine ruminal protein degradability. The most commonly used protease enzyme was the enzyme which has been extracted from Streptomyces griseus (Krishnamoorthy et al., 1983; Chaudhry, 2005, 2007). Aufrere et al. (1991) reported that in the French protein system (digestible proteins in the intestine, PDI), the enzymatic method is used as a laboratory method for nitrogen evaluation.

This research was conducted to determine in situ and in vitro rumen protein degradability of ESB and to develop regression equations to estimate in situ effective protein degradability from in vitro protein degradability values. Thus, these equations will facilitate the determination of in situ effective protein degradability of ESB by using in vitro protein degradability values of ESB.

\section{Materials and Methods}

\section{Feeds and Chemical Analyses}

The experiment was conducted using ten extruded full fat soybeans (ESB) collected from feed plants located different provinces in Turkey. A sample of each ESB was ground to pass $1 \mathrm{~mm}$ sieve using Retsch ZM200 laboratory mill and analysed for dry matter (DM, method 930.15), crude ash (CA, method 942.05), ether extract (EE, method 920.39) according to procedures of AOAC (1995) and for Crude fiber (CF), neutral detergent fiber (NDF), acid detergent fiber (ADF), acid detergent lignin (ADL) by the procedure of Van Soest et al., (1991). Total $\mathrm{N}$ was assayed by Micro Kjeldhal (AOAC method, 984.13. 1995) and crude protein (CP) content was calculated by multiplying $\mathrm{N}$ by 6.25 in feeds and residues after incubations of in vitro and in situ. The chemical compositions of ESB were presented in Table 1.

\section{Animals}

Three Holstein dairy cows 5 years old and weighing $550 \pm 30 \mathrm{~kg}$ were fitted with permanent rumen cannula to measure ruminal degradability of ESB in International Center for Livestock Research and Training. Cows were fed with a total mixed ration containing $70 \%$ mixture of barley straw and alfalfa hay and $30 \%$ concentrate, 1.25 times above maintenance requirements on a dry matter basis. Chemical composition of forage and concentrate offered to animals was presented in Table 2. During in situ experiment cows were kept in individual stalls and allowed free access to water and fed twice daily at 08:00 and 17:00 $\mathrm{h}$.

\section{In Situ Method}

In situ rumen protein degradability was measured using the nylon bag technique (Orskov and McDonald, 1979) adapted by Michalet-Doreau et al., (1987). Five grams air-dry samples ground in same manner as before chemical analyses were weighed into $5 \times 10 \mathrm{~cm}$ polyester bags with $50 \mu \mathrm{m}$ pore size (Ankom R510) and suspended in the rumen of three cows as three replicates for $2,4,8$, 16, 48 and $72 \mathrm{~h}$. The bags were simultaneously inserted in the rumen after the morning meal and removed sequentially at end of each incubation time. After incubation, the bags were immediately rinsed under tap water and washed in a commercial washing machine for 5 minutes. The $0 \mathrm{~h}$ bags were not incubated in the rumen but followed the same washing procedure. After washing the bags were dried in a forced-air oven at $65^{\circ} \mathrm{C}$ for $48 \mathrm{~h}$ and the residues were analysed for crude protein content as it was explained in chemical analyses. In situ effective degradability of feed proteins $\left(\mathrm{INS}_{\mathrm{E}}\right)$ was calculated from the kinetics of in situ degradation using the equation below from Orskov and McDonald (1979), assuming that theoretical ruminal passage rate $(\mathrm{k})$ is $0.06 / \mathrm{h}$ for milking cows according to Verité et al., 1987.

Table 1 Chemical composition of ESB samples (Mean \pm SEM, percent of DM*)

\begin{tabular}{l|cccccccc}
\hline Feeds & DM & Ash & CP & EE & NDF & ADF & ADL & CF \\
\hline ESB $_{1}$ & 90.6 & 4.8 & 41.7 & 22.3 & 10.1 & 7.9 & 0.2 & 7.8 \\
ESB $_{2}$ & 88.4 & 4.6 & 41.4 & 21.4 & 14.2 & 10.9 & 0.5 & 9.5 \\
ESB $_{3}$ & 93.4 & 7.6 & 36.8 & 16.7 & 13.5 & 10.4 & 1.0 & 8.9 \\
ESB $_{4}$ & 89.7 & 4.7 & 41.7 & 21.3 & 10.4 & 8.3 & 0.8 & 8.0 \\
ESB $_{5}$ & 89.8 & 5.6 & 42.0 & 22.7 & 9.3 & 7.4 & 0.8 & 6.3 \\
ESB $_{6}$ & 94.4 & 5.5 & 38.7 & 18.9 & 10.2 & 7.9 & 0.8 & 6.9 \\
ESB $_{7}$ & 89.0 & 5.0 & 39.7 & 26.1 & 9.5 & 8.3 & 0.8 & 7.9 \\
ESB $_{8}$ & 94.5 & 6.4 & 34.5 & 20.4 & 9.7 & 6.7 & 0.7 & 5.6 \\
ESB $_{9}$ & 89.2 & 5.0 & 37.7 & 21.3 & 10.1 & 8.2 & 0.6 & 7.2 \\
ESB $_{10}$ & 90.3 & 5.0 & 38.6 & 17.9 & 9.9 & 8.1 & 0.7 & 5.4 \\
Mean & $90.9 \pm 0.72$ & $5.4 \pm 0.29$ & $39.3 \pm 0.80$ & $20.9 \pm 0.84$ & $10.7 \pm 0.54$ & $8.4 \pm 0.40$ & $0.7 \pm 0.07$ & $7.4 \pm 0.42$ \\
\hline
\end{tabular}

*ESB: Extruded full fat soybean; DM: Dry matter; CP: Crude protein; EE: Ether extract; NDF: Insoluble fiber in neutral detergent solution; ADF: Insoluble fiber in acid detergent solution; ADL: Acid detergent lignin; CF: Crude fiber

Table 2 Chemical composition of animal's diet ( $\mathrm{g} / \mathrm{Kg} \mathrm{DM}$ basis)

\begin{tabular}{l|lllllllll}
\hline Concentrate & DM & CA & CP & EE & NDF & ADF & ADL & CF & ME (Mcal/Kg) \\
\hline Feeds & 890.3 & 105.5 & 194.9 & 16.6 & 339.7 & 288.5 & 58.5 & 219.5 & 2.18 \\
Alfalfa hay & 957.7 & 73.6 & 34.5 & 5.5 & 779.7 & 531.7 & 147.3 & 431.4 & 1.31 \\
Barley straw & 922.6 & 59.2 & 102.4 & 18.8 & 206.9 & 76.6 & 6.2 & 56.6 & 2.95 \\
\hline
\end{tabular}

DM: Dry matter; CP: Crude protein; EE: Ether extract; NDF: Insoluble fiber in neutral detergent solution; ADF: Insoluble fiber in acid detergent solution; ADL: Acid detergent lignin; CF: Crude fiber; ME: Metabolizable energy 
The effective degradability $\left(\mathrm{INS}_{\mathrm{E}}\right)$, corresponding to the theoretical degradability in the French protein system proposed by Verité et al., (1987) was calculated, weighted to account for rumen outflow rate, using the equation of Orskov and McDonald (1979):

$$
\mathrm{INS}_{\mathrm{E}}=\mathrm{a}+\mathrm{bc} /(\mathrm{c}+\mathrm{k})
$$

Where $\mathrm{INS}_{\mathrm{E}}$ is the in situ effective degradability; a is the fraction of rapidly solubilized protein; $b$ is the fraction of potentially degradable protein; $\mathrm{c}$ is the fractional rate constant for the disappearance of fraction $\mathrm{b}(/ \mathrm{h}) ; \mathrm{k}$ is rumen outflow rate.

\section{In Vitro Method}

Enzymatic degradation of ESB was measured by enzymatic hydrolysis for $1 \mathrm{~h}\left(\mathrm{INV}_{1}\right)$ and $24 \mathrm{~h}\left(\mathrm{INV}_{24}\right)$ by protease extracted from Streptomyces griseus in a boratephosphate buffer at $\mathrm{pH} 8$ as described by Aufrere and Cartailler, (1988). The $\mathrm{INV}_{1}$ and $\mathrm{INV}_{24}$ values were the percentage of the initial nitrogen content of ESB to the amounts of nitrogen degraded after 1 and $24 \mathrm{~h}$ hydrolysis. The enzyme solution was obtained by mixing $2 \mathrm{~g}$ of $S$. griseus protease (type XIV, Sigma no. P-5147; 3.5 titratable units $/ \mathrm{mg}$ ) with $1000 \mathrm{ml}$ of phosphoborate buffer ( $\mathrm{pH}$ 8.0, PBB), prepared by dissolving $12.20 \mathrm{~g}$ sodium dihydrogen phosphate $\left(\mathrm{NaH}_{2} \mathrm{PO}_{4} 2 \mathrm{H}_{2} \mathrm{O}\right)$ and $8.91 \mathrm{~g}$ sodium tetra borax $\left(\mathrm{Na}_{2} \mathrm{~B}_{4} 0_{7} 10 \mathrm{H}_{2} \mathrm{O}\right)$ in distilled water and $\mathrm{pH}$ of the solution adjusted at 8 with $1 \mathrm{~N} \mathrm{NaOH}$ and making up to $1000 \mathrm{~mL}$. Each ESB sample $(0.5 \mathrm{~g})$ was incubated in an $80 \mathrm{~mL}$ pyrex tube, with $0.5 \mathrm{ml}$ enzyme solution and $0.5 \mathrm{ml}$ tetracycline solution (Sigma no. T$3258,10 \mathrm{mg} / 100 \mathrm{~mL}$ PBB). At the initiation of the incubation period, $0.5 \mathrm{mg}$ nystatin (Sigma no N- 3503) and $50 \mathrm{ml} \mathrm{PBB}$ was added to each tube. Before incubation, ESB samples were milled to pass a $1 \mathrm{~mm}$ screen and $0.5 \mathrm{~g}$ samples were weighed in centrifugation tubes. Each sample was incubated in duplicate in 2 batches in a shaking water bath (Heto SBD 50) at $40^{\circ} \mathrm{C}$ for 1 and $24 \mathrm{~h}$. Extracted soybean meal was used as a reference feed for 1 and $24 \mathrm{~h}$ in each batch. Duplicate blank tubes without samples were incubated for $24 \mathrm{~h}$. In vitro enzyme assay was run as triplicate. Following incubations, the tubes were centrifuged for $5 \mathrm{~min}$ at 3000 rpm. Then the samples were filtered using filter paper (Whatman 54), residue was washed with deionize water, and $\mathrm{N}$ on the $10 \mathrm{~mL}$ supernatant was analysed by micro Kjeldhal. The quantity of $\mathrm{N}$ degraded was calculated as the fraction of that present before incubation, after adjustments for the relative blanks and the average change in 1 and $24 \mathrm{~h}$ solubility of the extracted soybean meal between the 2 batches.

\section{Statistical Methods}

The in situ effective degradability of feed proteins $\left(\mathrm{INS}_{\mathrm{E}}\right)$ was determined by Neway. Correlations between the $\mathrm{INS}_{\mathrm{E}}$ and the enzymatic in vitro protein degradability for 1 and $24 \mathrm{~h}\left(\mathrm{INV}_{1}\right.$ and INV24) were tested by simple linear regression. Minitab (Version 16) statistical program was used for regression analysis.

\section{Results and Discussions}

Chemical Composition of Extruded Soybean

The average DM, ash, CP, EE, NDF, ADF, ADL and CF values of ESB samples as percent of DM were $90.9 \%$, $5.4 \%, 39.3 \%, 20.9 \%, 10.7 \%, 8.4 \%, 0.7 \%$ and $7.4 \%$ respectively (Table 1).

\section{In situ and In Vitro Degradability for Extruded} Soybean

The mean $\mathrm{INS}_{\mathrm{E}}$ value of $10 \mathrm{ESB}$ samples was found as $58.05 \%$; $\mathrm{INS}_{\mathrm{E}}$ values of ESB samples are higher than $\mathrm{INV}_{1}$ and $\mathrm{INV}_{24}$ values (Table 3 ). The values of $\mathrm{INV}_{24}$ were two times of the values of $\mathrm{INV}_{1}$. The mean $\mathrm{INV}_{1}$ value of ESB was $20.24 \%$ and the mean $\mathrm{INV}_{24}$ value was $41.46 \%$.

\section{The relationship between in situ and in vitro protein} degradability of ESB

A correlation coefficient and regression were used to compare in vitro enzymatic protein degradability with in situ effective protein degradability for ESB. The correlation values and prediction equations of in situ effective degradability of ESB from enzymatic hydrolysis $\left(\mathrm{INV}_{1}\right.$ and $\left.\mathrm{INV}_{24}\right)$ are presented in Table 4.

All the correlation coefficients and regression equations that predict $\mathrm{INS}_{\mathrm{E}}$ from in vitro protein degradability at $1 \mathrm{~h}$ and $24 \mathrm{~h} \quad\left(\mathrm{INV}_{1}\right.$ and $\left.\mathrm{INV}_{24}\right)$ and together $\mathrm{INV}_{1}-\mathrm{INV}_{24}$ were found statistically significant $(\mathrm{P}<0.05)$. Prediction of in situ degradability from $\mathrm{INV}_{24}$ increased the correlation coefficient slightly $(\mathrm{P}<0.05)$ compare to in situ degradability from $\mathrm{INV}_{1}$, although it did not cause any change in the residual standard error of regression equations $(\mathrm{S})$. Also prediction of $\mathrm{INS}_{\mathrm{E}}$ from both together in vitro $1 \mathrm{~h}$ and $24 \mathrm{~h}\left(\mathrm{INV}_{1}-\mathrm{INV}_{24}\right)$ resulted slightly higher correlation coefficient $(\mathrm{r}=0.837)$.

The Rumen Degradation Characteristics of Extruded Full Fat Soybean

The rumen degradation characteristics of ESB were shown in Table 5. The washing loss of CP in ESB was found higher than the rapidly degradable fraction of $\mathrm{CP}$ in ESB $(33.65 \%$ versus $31.07 \%)$. The rate of $\mathrm{CP}$ disappearance and slowly degradable protein were 0.03 $1 / \mathrm{h}$ and $79.21 \%$ respectively.

The CP levels of ESB used in the study ranged from $36.8 \%$ to $42.0 \%$. Bargalea et al. (1999) (39.55\%, 39.76\% and 39.54\%), Demir and Şekeroğlu (2000) (36.62\%), Griffiths (2004) (40.5\%), Gonzalez et al. (2002) $(41.4 \%$ to $42.5 \%)$, Nowak et al. (2005) $(36.4 \%, 36.9 \%$ and $36.8 \%$ ) had reported similar CP values to that of ESB in this study. In the present study CP levels of ESB are higher than the work done by Troegeler-Meynadier et al. $2006(33.8 \%)$. Ether extract values of ESB ranged from $16.7 \%$ to $26.1 \%$. These values are similar to EE reported by Bargalea et al. (1999) $(21.42 \%, 22.13 \%$ and $20.63 \%)$, by Demir and Şekeroğlu (2000) (16.24\%), by Gonzalez et al. (2002) (between $21.6 \%$ and $24.9 \%$ ), by Griffiths (2004) (17.3\%), by Nowak et al. (2005) (19.1\%, 18.4\% and $18.0 \%$ ), by Troegeler-Meynader et al. (2006) $(17.1 \%)$. 
Table 3 In situ and in vitro degradability of ESB*

\begin{tabular}{|c|c|c|c|}
\hline Feeds & $\mathrm{INS}_{\mathrm{E}}$ & $\mathrm{INV}_{1}$ & $\mathrm{INV}_{24}$ \\
\hline $\mathrm{ESB}_{1}$ & 62.77 & 24.29 & 48.08 \\
\hline $\mathrm{ESB}_{2}$ & 61.20 & 18.38 & 39.19 \\
\hline $\mathrm{ESB}_{3}$ & 52.80 & 14.27 & 32.59 \\
\hline $\mathrm{ESB}_{4}$ & 63.50 & 23.83 & 47.10 \\
\hline $\mathrm{ESB}_{5}$ & 62.35 & 28.96 & 55.05 \\
\hline $\mathrm{ESB}_{6}$ & 56.17 & 22.31 & 45.20 \\
\hline $\mathrm{ESB}_{7}$ & 57.43 & 19.51 & 39.49 \\
\hline $\mathrm{ESB}_{8}$ & 51.98 & 16.33 & 29.84 \\
\hline $\mathrm{ESB}_{9}$ & 60.56 & 22.68 & 44.28 \\
\hline $\mathrm{ESB}_{10}$ & 51.73 & 11.81 & 33.81 \\
\hline Mean & $58.05 \pm 1.472$ & $20.24 \pm 1.638$ & $41.46 \pm 2.502$ \\
\hline
\end{tabular}

Table 4 Prediction equations for in situ protein degradability from in vitro enzymatic hydrolysis of ESB

\begin{tabular}{l|ccc}
\hline \multicolumn{1}{c|}{ Parameters } & \multicolumn{3}{|c}{ ESB } \\
\hline Y & $\mathrm{INS}_{\mathrm{E}}$ & $\mathrm{INS}_{\mathrm{E}}$ & $\mathrm{INS}_{\mathrm{E}}$ \\
No of samples & 10 & 10 & 10 \\
Constant & 0.4323 & 0.3752 & 0.3950 \\
$\mathrm{INV}_{1}$ & 0.7362 & & 0.3320 \\
$\mathrm{INV}_{24}$ & & 0.4971 & 0.2870 \\
$\mathrm{r}$ & 0.822 & 0.828 & 0.837 \\
$\mathrm{~S}$ & 0.028 & 0,028 & 0.029 \\
$\mathrm{P}$ & 0.004 & 0.003 & 0.015 \\
\hline
\end{tabular}

Table 5 Rumen degradation characteristics of ESB*

\begin{tabular}{l|c}
\hline \multicolumn{1}{c|}{$\mathrm{n}$} & 10 \\
\hline $\mathrm{A}(\%)$ & $33.65 \pm 1.00$ \\
$\mathrm{a}(\%)$ & $31.07 \pm 1.17$ \\
$\mathrm{~b}(\%)$ & $79.21 \pm 2.17$ \\
$\mathrm{c}(1 / \mathrm{h})$ & $0.03 \pm 0.003$ \\
$\mathrm{INS}_{\mathrm{E}}(\mathrm{k}=0.06)$ & $0.58 \pm 0.02$ \\
\hline
\end{tabular}

ESB: Extruded full fat soybean; n: No of samples; A: Washing loss (\%); a: Rapidly degradable fraction of CP $(\%)$; b: Slowly degradable fraction of CP (\%); c: Rate of CP disappearance $(1 / \mathrm{h})$; $\mathrm{INS}_{\mathrm{E}}$ : The effective degradability of $\mathrm{CP}$; $\mathrm{k}$ : rumen outflow rate $*($ Mean $\pm \mathrm{SEM})$

DM values of ESB ranged from $88.4 \%$ to $94.5 \%$ with an average of $90.9 \%$. These values are similar to those reported by Demir and Şekeroğlu (2000) (91.24\%), by Nowak et al. (2005) (90.5\%, 91.3\% and 90.8\%), and by Griffiths (2004) (92.5\%) and they were lower than those reported by Bargalea et al. (1999) $(96.25 \%, 96.27 \%$ and $96.28 \%$ ). The CA values of ESB in present study ranged from $4.6 \%$ to $7.6 \%$ which are similar to the values reported by Bargalea et al. (1999) $(4.65 \%, 4.72 \%$ and $4.67 \%$ ), by Demir and Şekeroğlu (2000) (4.81\%), by Gonzalez et al. (2002) (between $4.82 \%$ and $6.24 \%$ ), by Griffiths (2004) (5.2\%), by Nowak et al. (2005) (5.1\%, $5.2 \%$ and $5.2 \%$ ). In the study NDF and ADF values of ESB were $9.3 \%$ to $13.5 \%$ and $6.7 \%$ to $10.7 \%$ respectively and they are lower than those reported by TroegelerMeynadier et al. (2006) (NDF: $27.8 \%$ and ADF: 14.8\%) and by Nowak et al. (2005) (NDF: 29.6\%, 27.6\%, 27.8\%; ADF: $20.4 \%, 19.3 \%$ and $19.2 \%$ ). NDF values of ESB were determined by Gonzalez et al., 2002 as between $12.3 \%$ and $19.6 \%$ which are also somewhat higher than the relevant values of this study but $\mathrm{ADF}$ values reported by same researchers (between $7.05 \%$ and $10.9 \%$ ) were similar to ADF values in this study. CF values (5.6\% to $9.5 \%$ ) in the present study are similar to those reported by Demir and Şekeroğlu (2000) (5.48\%), by Nowak et al. (2005) $(6.8 \%, 6.4 \%$ and $6.0 \%)$, but they are lower than those written by Griffiths (2004) (11\%), by Bargalea et al. (1999) $(13.9 \%, 13.8 \%$ and $16.6 \%)$.

INS $_{\mathrm{E}}$ values of $10 \mathrm{ESB}$ samples ranged from $51.98 \%$ to $63.50 \%$ and the mean $\mathrm{INS}_{\mathrm{E}}$ value was $58.05 \%$. Gonzales et al. (2002) have reported that protein values of soy products for ruminants increased with decreasing ruminal effective protein degradability by heat treatment. As reported by Nowak et al. (2005); INS $_{\mathrm{E}}$ values of ESB were found between $57.3 \%$ and $71.3 \%$ which were smaller than that of untreated soybean $\left(\mathrm{INS}_{\mathrm{E}} 83.10 \%\right)$ and higher than those of ESB heat treated at $165^{\circ} \mathrm{C}\left(\mathrm{INS}_{\mathrm{E}}\right.$ $44.03 \%)$, at $145^{\circ} \mathrm{C}\left(\mathrm{INS}_{\mathrm{E}} 50.08 \%\right)$ and $155^{\circ} \mathrm{C}\left(\mathrm{INS}_{\mathrm{E}}\right.$ $50.26 \%$ ) where $\mathrm{k}$ has been taken as 0.06 . The rumen outflow rate was also effective on $\mathrm{INS}_{\mathrm{E}}$, therefore Griffiths (2004) found that $\mathrm{INS}_{\mathrm{E}}$ values of same ESB $39.9 \%$ and $42.7 \%$ when rumen outflow rate $(\mathrm{k})$ taken as $0.08 \mathrm{1} / \mathrm{h}$ and $0.06251 / \mathrm{h}$ respectively. Griffiths (2004) also indicated that protein sources were used in limited quantities in rations due to their high rumen degradability, extrusion allowed these sources to be used at higher levels. In situ effective protein degradability of ESB $\left(\mathrm{INS}_{\mathrm{E}}\right)$ in this study is higher than those of found by Nowak et al. (2005) and by Griffiths (2004). The reason for the differences; could be caused by the chemical composition of feed samples (Gonzalez et al. 2002), the pore size of nylon bags, the particle size of the feed samples, differences between cannulated animals, differences in the processing of protein sources (Canbolat, 2005), differences in the rations consumed by animals (Yalçın et al. 1998; Yörük et al. 2003; Deniz et al. 2004). Kirkpatrick and Kennelly (1987) reported that the degradability of $\mathrm{CP}$ increases with increasing $\mathrm{CP}$ level in the ration.

The degradability characteristics of ESB; a, b and c are; $31.07 \%, 79.21 \%$ and $0.031 / \mathrm{h}$, respectively. These results are similar with the Gonzales (2002) results $(\mathrm{a}, \mathrm{b}$ and c; 14.9\%-36.1\%; 63.9\%-85.1\%; $0.04-0.061 / \mathrm{h}$ respectively) but higher than Griffiths (2004) relevant values (b and c; $54.1 \%$ and $0.0221 / \mathrm{h}$ respectively) although the rapidly degradable fraction of CP (a) similar to that of (a) value reported by the latest mentioned author. In the present study, the slowly degradable fraction of CP (b) is similar to the (b) values $(83.47 \%$, $83.38 \%$ ) of $\mathrm{ESB}$ treated at $145^{\circ} \mathrm{C}$ and $155^{\circ} \mathrm{C}$ reported by Nowak et al. (2005), but it is lower than the (b) value $(96.08 \%)$ of $\mathrm{ESB}$ treated at $165^{\circ} \mathrm{C}$ reported by same researchers. The rumen rapidly degradable fraction (a) in this study is higher than the (a) values of the whole temperature treatments $(6.51 \%$ to $11.56 \%)$ found by Nowak et al. (2005), however, the rate of disappearance of $\mathrm{CP}(\mathrm{c})$ is lower than that of (c) found in the mentioned study. In the present study, the washing loss (A) was found to be somewhat higher than the rapidly degradable fraction (a). 
The INS $\mathrm{I}_{\mathrm{E}}$ value of ESB (58.05\%) was higher than the $\mathrm{INV}_{1}$ and $\mathrm{INV}_{24}$ values $(20.24 \%$ and $41.46 \%$ respectively). As it was stated by Aufrere et al. (1991), in situ method is used as a reference method since it provides the most precise result for estimation of rumen protein degradability. It has been indicated that there were two possible causes of in situ and in vitro method differences; the loss of dry matter induced by the pore size of the nylon bags and the second; the residual $\mathrm{N}$ in the bags corresponds not only the non-degraded feed $\mathrm{N}$, but also to that of microbes attached to particles remaining in the bags (Michalet Doreau, 1991). Also, it has been reported that the microbial contamination varies according to the nature of the feed (Nocek, 1988).

In this study, the regression equations that estimate $\mathrm{INS}_{\mathrm{E}}$ from $\mathrm{INV}_{1}, \mathrm{INV}_{24}$ and $\mathrm{INV}_{1}-\mathrm{INV}_{24}$ were found that statistically significant $(\mathrm{P}<0.05)$. Although estimating in situ degradability from INV24 has increased the correlation coefficient slightly $(0.828>0.822 ; \mathrm{P}<0.05)$ compared to predicting it from INV1, it did not cause any change in the residual standard error of regression equations $(\mathrm{S}=0.028)$. The estimation of $\mathrm{INS}_{\mathrm{E}}$ from $\mathrm{INV}_{1^{-}}$ $\mathrm{INV}_{24}$ led to a higher correlation coefficient $(\mathrm{r}=0.837)$ than the estimation of $\mathrm{INS}_{\mathrm{E}}$ from $\mathrm{INV}_{1}$ and $\mathrm{INV}_{24}$. However, the use of $\mathrm{INV}_{1}$ for estimation of INS $\mathrm{IN}_{\mathrm{E}}$ may be suitable with less effort, less expense and shorter time. Roe et al., (1991), found a similar correlation coefficient $(r=0.82)$ in estimating the $\mathrm{INS}_{\mathrm{E}}$ value of the heat-treated full fat soybean from the in vitro value but standard errors of the mean of regression equations were higher $(\mathrm{r}=0.37)$. Poos-Floyd et al. (1985) found that in the estimation of in situ rumen degradability from all proteolytic enzymes at 1 $\mathrm{h}$ and $4 \mathrm{~h}$ incubation times gave statistically significant correlations. (Nocek, 1988) reported that the in vitro protein solubility at $1 \mathrm{~h}$ to 3 hours incubations was highly correlated with ruminal protein degradability. Aufrere et al. (1991) reported that in situ degradability can be estimated much more accurately by enzymatic method, even when only $\mathrm{INV}_{1}$ is used for feed mixtures. They have noted that the degradability of many feed samples, except those that were very slowly degraded in the rumen, was highly dependent on the amount of protein degraded in the early times of incubation.

As a result; the relationship and regression equations found in this study provide in situ validity of the in vitro method, which is easier and less expensive than the in situ method in predicting the effective protein degradability of ESB. These equations can be used by feed manufacturers and researchers to estimate in situ protein degradability from in vitro values.

\section{Acknowledgements}

The main author would like to state that this research is an article produced from her $\mathrm{PhD}$ project named "Relationship between in situ and in vitro rumen protein degradability of full fat soybean, soybean meal and extruded soybean"

The authors are very appreciative of financial support of Agricultural Researches and Policies General
Directorate, and also express appreciation to the manager and staff of International Center for Livestock Research and Training for their support.

\section{References}

AFRC. 1987. Technical Committe on Responses to Nutrients. Rep. No: 2. Characterisation of feedstuffs: Nitrojen. Nutr. Abstr. Rev. Ser. B., Livestock Feeds Feeding 57: 713 - 736.

AOAC. 1995. Association of Official Analytical Chemists; 16th Edition, Arlington, Virginia, USA.

Assoumani MB, Vedeau F, Jacquot L, Sniffen CJ. 1992. Refinement of an enzymatic method for estimating the theoretical degradability of proteins in feedstuffs for ruminants. Animal Feed Science and Technology, 39: 357-368.

Aufrere J, Cartailler D. 1988. Mise au point d'une methode de laboratoire de prevision de la degradabilite des proteines alimentaires des aliments concentres dans le Rumen. Ann. Zootect., 37: 255-270.

Aufrere J, Graviou D, Demarquilly C, Verite R, Michhalet-Doreau B, Chapoutot P. 1991. Predicting in situ degradability of feed proteins in the rumen by two laboratory methods (solubility and enzymatic degradation). Anim Feed Science and Technology, 33: $97-116$.

Bargalea PC, Fordb R.J, Sosulskic FW, Wulfsohnb D, Irudayarajd J. 1999. Mechanical oil expression from extruded soybean samples. JAOCS, 76: 223-229

Broderick GA, Wallace RJ, Orskov ER, Hansen L, 1988. Comparison of estimates of ruminal protein degradation by in vitro and in situ methods. Journal of Anim Science, 66: 1739-45.

Calsamiglia S, Stern M. 1995. A three step in vitro procedure for estimating intestinal digestion of protein in ruminants. Journal of Anim. Science, 73: 1459-1465.

Chamberlain AT, Wilkinson JM. 1998. Feeding the dairy cow (Second edition). Painshall, Church Lane, Welton, Lincoln, LN2 3LT, UK.

Chaudhry AS. 2005. Comparing two commercial enzymes to estimate in vitro proteolysis of purified and semi purified proteins. Journal of Anim Physiol Anim Nutrition, 89: 403-412.

Chaudhry AS. 2007. Enzymic and in sacco methods to estimate rumen degradation of food protein in cattle. Journal of Science of Food and Agriculture, 26: 2617-2624.

Cömert M, Sayan Y. 2000. Ruminantların beslenmesinde kullanılan bazı yemlerin protein içeriklerinin rumende parçalanabilme özellikleri üzerine bir araştırma.. Ege Üniv. Ziraat Fak. Derg., 37: 145-152.

Demir E, Şekeroğlu A. 2000. Ekstrude tam yağlı soya, Fermanko ve Yucca Ekstraktının Etlik Piliçlerdeki Etkileri. Tavukçuluk Araştırma Dergisi, 2: 31-35.

Deniz S, Karslı MA, Nursoy H, Kutlu MS. 2004. Ruminantların beslenmesinde yaygin olarak kullanılan proteince zengin bazı yem hammaddelerinin protein parçalanabilirlik özelliklerinin in sacco yöntemle belirlenmesi. Turkish Journal of Veterinary and Animal Sciences, 28: 1079-1086.

Griffiths JB. 2004. The effect of extrusion on the degradability parameters of various vegetable protein sources. Thesis submitted in partial fulfilment of the requirements for the degree of MSc (Agricultural Sciences) University of Stellenbosch. file:///C:/Users/HP/Downloads/griffiths_effect_ 2004.pdf. Available from http://scholar.sun.ac.za/handle/ 10019.1/16333 [Accessed 18.07.2017].

Gonzalez J, Andres S, Rodriguez AC, Alvir MR. 2002. In situ evaluation of the protein value of soybean meal and processed full fat soybeans for ruminants. Animal Research. 51: 455-464.

Kirkpatrick BK, Kennelly JJ. 1987. In situ degradability of protein and dry matter from single protein sources and from a total diet. Journal of Animal Sciences. 65: 567-576.

Krishnamoorthy UK, Sniffen CJ, Stern MD, Van Soest PJ. 1983. Evaluation of a mathematical model of rumen digestion and in vitro simulation of rumen proteolysis to estimate the rumenundegraded nitrogen content of feedstuff. British Journal of Nutrition, 50: 555-568. 
McDonald P, Edwards RA, Greenhalgh JFD, Morgan CA. 2011. Animal Nutrition (Seventh Edition). Pearson, Harlow, Essex, UK: Pearson Education Limited. ISBN-13: 978-1408204238

Michalet-Doreau B, Verite R, Chapoutot P. 1987. Methodologie de mesure de la degradabilite in sacco de I'azote des aliments dans le Rumen, Bull. Tech., Cent. Rech. Zootech. Vet. Theix, INRA, 69: 5-7.

Nocek J. 1988. In situ and other methods to estimate ruminal protein and energy digestibility: A review. Journal of Dairy Science, 71: 2051-2069.

Nowak W, Michalak S, Wylegała S. 2005. In situ evaluation of ruminal degradability and intestinal digestibility of extruded soybeans. Czech J. Anim. Sci., 50: 281-287.

Orskov ER, Mc Donald I. 1979. The estimation of protein degradability in the rumen from incubation measurements weighted according to rate of passage. J. Agric. Sci., 92: 499503.

Poos-Floyd M, Klopfenstein T, Britton RA. 1985. Evaluation of laboratory techniques for predicting ruminal protein degradation. Journal of Dairy Science, 68: 829-839.

Roe MB, Chase LE, Sniffen CJ. 1991. Comparison of in vitro techniques to the in situ technique for estimation of ruminal degradation of protein. Journal of Dairy Science, 74: 1632 1640 .
Susmel P, Stefanon B, Mills CR, Colitti M. 1989. The evaluation of PDI concentration in some ruminant feedstuffs : a comparison of in situ and in vitro protein degradability. Ann. Zootech., 38: 269-283.

Troegeler-Meynadier A, Nicot MC, Enjalbert F. 2006. Effects of heating process of soybeans on ruminal production of conjugated linoleic acids and trans-octadecenoic acids in situ. Revue de médecine vétérinaire, 2006, 157: 509-514.

Verité R, Michalet-Doreau B, Chapoutot P, Peyreaud JL, Poncet C. 1987. Revision du systeme des Proteines Digestibles dans I'Intestin (P.D.I.). Bull. Tech. C.R.Z.V. Theix, I. N.R.A. 70: 1934.

Yalçın S, Şehu A, Önol AG. 1998. Straw degradability as a predictor of intake and growth rate in sheep. British Society of Anim. Sci., 67: 485-490.

Yörük MA, Gül M, Aksu T, Bolat D. 2003. Formaldehitle muamele edilmiş soya küspesinin rumende parçalanma özellikleri. YYÜ Vet Fak Derg., 14:1-5. 